\title{
The Socio-Cultural Impress on the Promotion of Self-Directed-Learning in Algerian Universities
}

\author{
Hanaà BERREZOUG \\ Department of English Language and Literature \\ Faculty of Letters, Languages and Art \\ Saida University, Algeria \\ Email: mbhanae@yahoo.com
}

Received: 4/29/202

Accepted: 9/6/2021

Published: 9/24/2021

\section{Abstract}

The Algerian universities have witnessed significant changes since the establishment of the three-tier system composed of Licence, Master, and Doctorate (LMD). The latter necessitates many changes in the learning process as well as teaching methods. Yet, to achieve self-directed learning, the learner should first achieve autonomy at the personal level. Thus, this paper is mainly devoted to analyzing the impress of Algerian cultural and social traditions on the development of self-directed learning. This study addresses the following question: Do the Algerian cultural and social traditions enhance and facilitate self-directed learning or impede its implementation at university? The main aim of this paper is to investigate the aspects of the Algerian culture that hinder the promotion of self-directed learning. The research has been conducted in Saida University among Master students. To investigate the socio-cultural impact on the development of self-directedness, the researcher used a questionnaire and an interview that was related to Hofstede's six-D Model. Discussing the Algerian culture through the lens of Hofstede's six-D Model helped the researcher to diagnose the reasons behind the failure to promote self-directedness. The main finding of this research is that the collectivist nature of the Algerian culture retards the progress of self-directed learning. This paper also suggests that if the Algerian culture does not favor self-directed learning, educators should adopt new approaches and strategies that engage their learners in the learning experiences. Educators should counterbalance the parochial and paternalistic traditions with glocalization and multiple perspective curricula.

Keywords: Algerian socio-culture, Algerian universities, autonomy, democracy, glocalization, higher education, individualism, Hofstede's six-D model, self-directed learning, socio-cultural impress

Cite as: Berrezoug, H. (2021). The Socio-Cultural Impress on the Promotion of Self-DirectedLearning in Algerian Universities, Arab World English Journal, 12 (3) 216-231.

DOI:https://dx.doi.org/10.24093/awej/vol12no3.15 


\section{Introduction}

When the researcher first started teaching at university, the Licence/ Master/ Doctorate program was not yet applied in my university. The researcher started teaching in a very traditional way, namely teacher-directed learning that most of her colleagues adopted. The learning process was centered on the teacher. The researcher used to present a lecture whose objectives she was responsible to design, and in the final run, the exam papers of her students were mere reformulations of the talks the researcher used to give during her classes. Two years later, the researcher has submitted an LMD program for my department and decided to engage her students in the syllabus design of the units she was in charge of. In this context, the researcher asked her students to revise the syllabus and add or omit things that they consider necessary or irrelevant, respectively. This long and gradual shift from teacher-directed learning to self-directed learning was marked by many obstacles. The most significant stumbling block to the achievement of the researcher's goal was the students' fixed view of the learning process as conceived through the hierarchical relationship between the teacher and the learner. Most students were astonished when asked to deliver their opinion on the syllabus designed by the teacher. When students learned that the teacher warmly welcomed any changes they might bring to the syllabus, none of them viewed this as a step towards self-directed learning. Instead, they judged the researcher as a lazy teacher who depends on her students to fulfill what they considered her duty. Thus, to achieve self-directed learning in Algerian universities seems improbable as long as the Algerian socio-culture continues to view the learning process from a hierarchical standpoint.

Two main reasons motivate the present study. The first and most important is the shift towards distance learning in Algerian universities through the Moodle platform. If the performance of distance learning has become urgent, self-directed learning becomes one of the fundamental precepts in its implementation. The second reason is the urge to adapt universities to the 21st century technological advances that value online teaching, thus revolutionizing the traditional learning/teaching classroom setting. Therefore, as a teacher, one should achieve two essential things; digitize one's lectures and learn to correspond with learners in a distance learning context that goes hand in hand with face-to-face learning. These two objectives necessitate a crucial shift in the learning process from teacher-directed learning to self-directed learning since the teacher is no more fully in control of the learning process as s/he used to be in a traditional classroom. So, at this juncture, self-directed learning is no more an option but becomes a reality that all Algerian teachers should accept. The research question that is addressed in this paper is: what is the role of Algerian socio-culture in the implementation of self-directed learning? More precisely, this research seeks to find out whether Algerian socioculture enhances or impedes self-directed learning. The main objective of this research is to highlight the Algerian socio-cultural elements that contravene the progress of self-directed learning. When these elements are revealed, a fundamental pedagogical work needs to be conducted to promote self-directedness without compromising the Algerian collectivist cultural values.

\section{Literature Review}

To foster self-directed learning, it is first necessary to understand what it means and what prerequisites are required for its performance. Probably the most prevailing definition of selfdirected learning is that offered by Knowles (1975): 
In its broadest meaning, self-directed learning describes a process in which individuals take the initiative, with or without the help of others, in diagnosing their learning needs, formulating learning goals, identifying resources for learning, choosing and implementing appropriate learning strategies, and evaluating learning outcomes. (p.18)

Therefore, self-directed learning is utterly different from teacher-directed learning. In teacherdirected learning, the teacher is the chief executive in the classroom: he decides the course goals, defines course content, chooses exercises and assignments for the course, and ultimately grades and assesses the learners. As opposed to teacher-directed learning, self-direction in adult learning is centered on autonomous learning and puts significant emphasis on the self-imposed responsibility of the individual learner in the learning process. In a self-directed learning situation, many of the tasks allotted to the teacher in a classical teacher-directed classroom should be attributed to the learners. In this case, the teacher becomes a coach whose mission is to orient, negotiate and guide. Gibbons (2003) gave an illuminating distinction between the modes of learning when he notes, "In TDL, we teach students about the nature of flight; in SDL, we teach students how to fly. When students learn to fly, they "earn their wings."” (p.3) The least to be said about the distinction made by Gibbons is that it is judicious as long as it implicitly highlights the consequences of each mode of learning.

To uphold the shift to self-directed learning Knowles (1975) identified three reasons that justify his reasoning:

1. Individuals who take the initiative in learning learn more things and learn better than do people who sit at the feet of teachers possibly waiting to be taught.

2. Self-directed learning is more in tune with our natural processes of psychological development.

3. Many of the new developments in education put a heavy responsibility on the learners to take a good deal of initiative in their learning.

The first reason is probably the most significant and consequential one as Knowles implicitly explicates that self-directed learning yields active, innovative, and Promethean workers who take the initiative in the workforce. Instead, teacher-directed learning will undoubtedly result in passive workers who wait for decisions to be made for them.

According to Hanrahan (1998), Sinclair (2007), and Lamb (2009), the learning environment, including traditional-cultural aspects, crucially impacts students' learning, especially their autonomy in learning. If considers Brookfield's claim that self-directed learning is tightly related to Western cultures, then implementing self-directed learning in Algerian teaching becomes complex because of the significant impress of socio-cultural factors on education in general and students' learning in particular. Brookfield (1994) claimed that:

self-directed learning connects directly to a certain strain of progressive humanism (in North America) and Liberalism (in the UK), that places primary emphasis on the absolute necessity valuing adults' experiences and working to help them take control of their own learning (https://infed.org/mobi/self-directed-learning/) 
Not only did Brookfield classify self-directed learning as culturally Western, but he added: "the concept can be interpreted as the ultimate educational expression of capitalist ideology," leaving no room for non-capitalist countries to test self-directed learning. Brookfield's categorization builds on Knowles' canonical definition of self-directed learning whose most potential characteristic is independence and participatory behavior and attitude, which might be politically viewed as democratic learning. Naisbitt (1984) rightfully explains in this concern that "people whose lives are affected by a decision must be a part of the process of arriving at that decision" (p.159). This suggests that learners should collaborate with their teachers and the administrative staff in all matters that concern or affect their learning. Therefore, since this study focuses on Algerian universities, the question raised at this level is the following: Can we democratize education in non-democratic societies? One example of the absence of collaborative thinking in Algerian universities is represented by one practice exercised by the institution of the CPND (the National Pedagogical Committee of the Domain) that meets regularly to discuss pedagogical issues related to each field and standardize the syllabi relative to the Licence level throughout Algerian Universities. By so doing, the teacher comes into the classroom with a ready-made syllabus, and no other alternative than to impose the syllabus on his students. Whatever the advantages it might bring forth, this practice is at odds with the collaborative strategies that characterize self-directed learning.

One other characteristic of self-directed learning that is at odds with the Algerian socioculture is individualism. Triandis (1995) defines individualism as "a social pattern that consists of loosely linked individuals who view themselves as independent of collectives" (p.2). As opposed to collectivism, individualism is given more attention in adult learning psychology. Academics agree that people in individualistic cultures develop independent thinking early at school, and this will help them become independent citizens capable of creating new things once they enter the workforce. In his research, Braman (1998) concluded that self-directed learning is based on individualistic values such as "freedom," "independence," and "autonomy." To support his argument, he invites us to check whether the collectivist attitudes such as "conformity," interdependence," and "duty" are reliable in developing self-directed learning. He ultimately concludes that these collectivist values are irrelevant to the promotion of self-directed learning. In his seminal work, he points out,

Individualist attitudes and values are listed in positive terms and are deemed preferable to collectivistic attitudes and values, which are listed in negative terms. Every now and then, however, a positive collectivistic term (i.e., cooperation, interdependence, etc.) is listed among contradicting individualistic terms, yet the apparent contradiction goes unreconciled. Collectivism, compared to individualism, has not been given equal attention, consideration, or status as a basis for theory development in adult education. (p. 44)

Trying to draw a link between individualism and competitiveness as the latter is motivated by the former, Keddie (1980) noted that "the notion of individuality as a desirable personality goal is not universal, but is cultural specific and tends to be found in those cultures (such as ours) where high status is obtained by competitive individual achievement" (p.54). Thus, far from the tradition of collectivism, self-directed learning requires a minimum of individual responsibility and a high sense of competition not recommended in collectivist societies that highly value cooperation between members of the community. 
Many studies have been undertaken in the field of self-directed learning in Algeria. However, the available literature hardly tackles the issue from a cultural perspective. The works that have been conducted by academics deal with self-directed learning from a didactic viewpoint. Preoccupied with how to remedy things in the classroom, teachers often disregard the outside reasons that might interfere with the implementation of their strategies. Haddoune Sakraoui (2019), for instance, published an interesting study on how to integrate self-directed learning habits among EFL learners. Building her analysis on Blaschke (2012), Haddoune Sakraoui (2019)claimed that heutagogy is viewed "as a 'a continuum' of 'pedagogy' referring to strategies used for teaching children and 'andragogy' which is a concept used to depict strategies for teaching adults." (p.165)

Benchennane (2017) investigated the technological impress on self-directed learning among a group of LMD students. Benchennane (2017) recommended the use of ICT's noting that, "students enjoyed working by their own ... they also enjoyed working through technologies" (p.40). Another Algerian scholar interested in this scope of research is Ghout-Khenoune, editor of the LASIG Newsletter (learner autonomy special interest group). One paper by GhoutKhenoune particularly meets the objective of this research. In her work, she tries to answer whether the Algerian culture meets the requirements of learner autonomy. As a teacher at the University of Bejaia, Ghout-Khenoune (2019) recounted her initial frustration due to teachers' as well as learners' disregard for autonomy when she elucidated:

Many teachers argued that the Algerian learning culture is not conducive to autonomous learning. This was due to the dominance of exams in the educational system and exclusion of the learners from decision-making in relation to their learning. The result was a cohort of students that were passive, lacked initiative and were over-reliant on the teacher. In addition, many teachers expressed reluctance to promote learner autonomy in their classes without any in-service training (p. 9).

Convinced that there is a fertile ground for the implementation of learner autonomy in Algerian universities, Ghout-Khenoune (2019) concluded that there is a need to readjust the educational environment to promote autonomy. Her experience bears significance concerning practical implementation. In an attempt to remedy these flaws, Ghout-Khenoune planned in 2016 the introduction of two permanent teaching modules in the didactics Master program at the level of her department, namely "Learner Autonomy in EFL Learning" and "Language Learning Advising." She clarifies that the former "aims to raise awareness of learner autonomy, its philosophy and principles in pre-service teachers," while the latter:

introduces the domain of language learning advising as one way to promote autonomy in our education context. Students discover and discuss the advantages of reflection and dialogue to help manage their learning and become more autonomous. Students' positive feedback at the end of these two courses is the premise of a promising future of learner autonomy in the Algerian context (Ghout-Khenoune, 2019, p.10).

Although Ghout-Khenoune's work addressed the same question investigated in this paper, this study tackles the issue of self-directed learning and culture from a different angle. There have been very few attempts to investigate the coherence of the Algerian with the development of 
self-directed learning. Therefore, the ultimate goal of this paper is to explore the cultural elements that are at odds with the basics of self-directed learning. By spotting these cultural traits, the results can point out the need to conceive an SDL model that is congruent with Algerian culture.

First and foremost, this paper seeks to highlight one of the most important things that should not be overlooked when implementing self-directed learning, i.e. the socio-cultural environment of the learner.

The first section of this paper will deal with self-directed learning, its definition, and its main characteristics. For instrumental reasons, special attention will be paid to two aspects of selfdirected learning: democracy and individualism. The second part of this paper is dedicated to examining the Algerian culture through Hofstede's six Dimensions model. In the same vein, two parallel dimensions will be stressed: the Power distance index and individualism versus collectivism. The selection of these two dimensions will be handy in drawing conclusions about whether Algerian socio-culture contrasts or corresponds with the aspects of self-directed learning. The last part of this paper suggests that possible solutions to the problem can be provided by higher educators and policy-makers by designing multiple perspective curricula and reinforcing international exchange programs.

\section{The Algerian Culture and the Hofstede Six Dimensions Model}

Let us recall that two of the most prominent aspects of self-directed learning that have been highlighted so far are democracy and individualism. Thus, the present study will investigate the possibility of implementing self-directed learning in Algeria through these two aspects. In other words, this section will examine the main components of the Algerian culture and whether they happen to favor self-directed learning.

One study that the researcher considers very useful to this paper and that helps understand the teacher-learner relationship in Algeria is Hofsted's (1991) Culture's consequences. In this extensive research, Hofstede indicates that there are six dimensions of national culture. In this paper, the researcher will explore two of these dimensions, namely the power distance index, and individualism. The researcher has selected these two dimensions because the first one represents the dynamics of social relationships and the second one defines the personal traits of an individual in relation to his community. The diagram below demonstrates the scores of Algeria in the Six Dimensions Model set by Hofstede

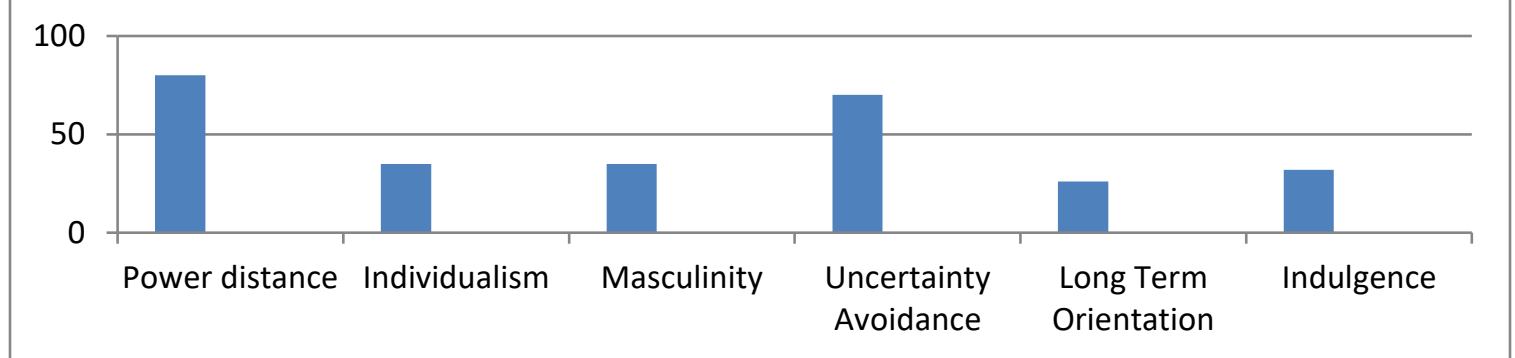

Figure 1. Estimated score of Algeria in the Hofstede's six-D model

Notel. Adopted from https://www.hofstede-insights.com/country/algeria/ 
As indicated in the diagram, Algeria scores 80 in the power distance index, 35 in terms of individualism, 35 in Masculinity, 70 in Uncertainty Avoidance, 26 in Long Term Orientation, and 32 in Indulgence. Before discussing these scores, let us first discuss Hofstede's definitions of the power distance index and individualism that will be stressed in this paper, and then see how they relate to the Algerian culture.

\section{The Power Distance Index}

One of the most important studies that proposed the classification of cultures is the one proposed by Hofstede in his Six Dimensions model. The first dimension in this model is the power distance index that relates to peoples' acceptance of unequal distribution of power. As defined by Hofstede (2011), Power distance is a concept that describes

The extent to which the less powerful members of organizations and institutions (like the family) accept and expect that power is distributed unequally. This represents inequality (more versus less), but defined from below not from above. It suggests that a society's level of inequality is endorsed by the followers as much as by the leaders. (p.9)

Thus, the power distance index refers to the relationships between people in society and how these relations are regulated by an unequal distribution of power that is considered legitimate. Individuals in cultures demonstrating a considerable power distance are very respectful of their superiors and naturally accept an unequal distribution of power. However, individuals in cultures showing a small power distance readily question authority and expect to participate in decisions that affect them.

In an attempt to highlight the difference between large power distance and small power distance cultures, Hofstede (2011) spotted ten fundamental points of difference between the two:

Table 1. Ten differences between small-and large-power distance societies

\begin{tabular}{|c|c|}
\hline Small Power Distance & Large Power Distance \\
\hline $\begin{array}{l}\text { 1.Use of power should be legitimate and is subject to } \\
\text { criteria of good and evil } \\
\text { 2. Parents treat children as equal } \\
\text { 3. Older people are neither respected nor feared } \\
\text { 4. student-centered education }\end{array}$ & $\begin{array}{l}\text { 1.Power is a basic fact of society antedating good or } \\
\text { evil; its legitimacy is irrelevant } \\
\text { 2. parents teach children obedience } \\
\text { 3. Older people are both respected and feared }\end{array}$ \\
\hline $\begin{array}{l}\text { 5. Hierarchy means inequality of roles, established for } \\
\text { convenience } \\
\text { 6. Subordinates expect to be consulted }\end{array}$ & $\begin{array}{l}\text { 4. teacher-centered education } \\
\text { 5. Hierarchy means existential inequality }\end{array}$ \\
\hline $\begin{array}{l}\text { 7. Pluralist governments based on majority vote and } \\
\text { changed peacefully } \\
\text { 8. Corruption rare ; scandals end political careers } \\
\text { 9. Income distribution in society rather even } \\
\text { 10. Religion stressing equality of believers }\end{array}$ & $\begin{array}{l}\text { 6. Subordinates expect to be told what to do } \\
\text { 7. Autocratic governments based on co-optation and } \\
\text { changed by revolution } \\
\text { 8. Corruption frequent; scandals are covered up } \\
\text { 9. income distribution in society very uneven } \\
\text { 10. Religion with a hierarchy of priests }\end{array}$ \\
\hline
\end{tabular}

Note 2. Adopted from Hofstede (2011, p. 9)

As indicated in the previous diagram, Algeria scores 80 in terms of power distance, just like China. This very high score means that Algeria is a large power distance society. Moreover, the Algerian culture can be defined through the ten aspects of Large power distance societies as 
detailed by Hofstede (2011) in the table above. Point two, for instance, is typically descriptive of the Algerian model. In Algeria, the parent-children relationship is not only based on obedience and reverence, but children cannot decide over personal matters without the consent of their parents. An example of this is the issue of marriage that is not a personal matter in Algeria; it is rather a family matter where every member of the family has a word to say about the future bride or groom. Without the consent of one's parents, one's marriage is considered unblessed in Algeria.

Moreover, young Algerian people do not consider older people as their equals, nor do the elderly do. A vivid example of this is the issue of invitation. In Algeria, when one organizes an event s/he can invite your older brother/ sister without necessarily inviting you, because the elderly are considered as family representatives. The younger ones, in this case, are not supposed to question this tradition because this is the norm.

Point four relates directly to this study. Hofstede (2011) concludes that in large power distance societies, education is teacher-centered. This leads to the conclusion that before promoting autonomy in educational circles, we should first encourage autonomy in family circles. As described by several scholars, in Algeria, the social, cultural, and educational characteristics have been strongly and deeply influenced by the Arab-Islamic heritage for centuries. One of the fundamental aspects of this heritage is to build up a society through harmony and hierarchy. Algerian culture, as well as other Arab countries which were influenced by the Islamic tradition, is classified as a high power distance culture. In such high power distance societies, the teacher-learner relationship is unequal; students are dependent on and should be respectful of their teachers. As culture and religion overlap in Algeria, three relationships might be viewed as the most important in society: God-subject, Father-child, and Teacher-Learner. The Algerian culture had developed an educational system and a teacherlearner relationship based on Ahmed Chawki's poem dedicated to the teacher that starts with:

$$
\text { قم للمعلم و فه التبجيلا كاد المعلم أن يكون رسو لا }
$$

This literally translates into, "stand up in reverence for the teacher for he almost be a prophet." This poem dedicated to the teacher seeks to establish a fixed hierarchical relationship between teachers and learners, a relationship where the latter should salute and revere the former. Therefore, this hierarchical relationship is legitimate, to borrow Hofstede's (2011) terms, and antedates good or evil. Consequently, this results in a traditional teaching-learning style that is qualified as teacher-centered.

Points seven and eight are also very indicative of Algeria. Algeria has been under a corrupted autocratic regime for 20 years where scandals were always covered up, and the result was that corruption had become even. This regime could not be changed without the revolution of February $22^{\text {nd }}, 2019$.

In one research conducted on Malay adult learners, Ahmad and Abdul Majid (2010) concluded that one significant characteristic of collectivist societies is that "members of groups do not speak up, or even express a contradictory point of view, instead social harmony is maintained and it is the hidden goal of every communication"(p. 255). This specific trait is true of Algerians, in general. In fact, it is so tricky in a collectivist society based on shared values to manifest one's disapproval of the social and culturally accepted norms. In patriarchal societies 
like Algeria, for instance, it is generally accepted that the wife takes care of the husband and is obedient to him. A person who believes otherwise is not welcome in the group. It is even considered taboo to think otherwise than the group. According to Ahmad and Abdul Majid (2010), people avoid speaking out their different viewpoints "so as to avoid losing face, which is a terrible thing to suffer in collectivist cultures throughout Asia, the Middle East and Africa." (p. 255)

\section{Individualism versus Collectivism}

Individualism versus collectivism is another critical dimension in the classification of cultures. Hofstede (2011) uses this dimension to address the degree of interdependence among members of society. In a detailed definition of individualism, Hofstede (2011) contrasts individualism with collectivism and explains:

Individualism on the one side versus its opposite, collectivism, as a societal, not an individual characteristic, is the degree to which people in a society are integrated in groups. On the individualist side we find cultures in which the ties between individuals are loose: everyone is expected to look after him/herself and his immediate family. On the collectivist side we find cultures in which people from birth onwards are integrated into strong, cohesive in-groups, often extended families (with uncles, aunts, and grandparents) that continues protecting them in exchange for unquestioning loyalty, and oppose other in-groups. (p. 11)

With a low score of 35 (see figure one), the Algerian individual is unlikely to be individualistic. As opposed to middle-class cultures, Algeria puts the emphasis more on collective values. In an attempt to highlight the difference between these two systems, Keddie (1980) explains, "The force of the research which has attempted to distinguish between middle and working class cultures has stressed that while the middle class are oriented towards the value of individual achievement, working class culture places emphasis on collective values" (pp.54-55). In his review of self-directed learning research, Brookfield (1984) confirms this hypothesis when he laments the non-performance of working-class learners.

A closer look at the Algerian family structure will probably confirm this hypothesis. The Algerian society is a collectivist one because of the family values it maintains. The Algerian family structure is patrilineal in terms of descent. Tiliouine and Achoui (2018) opine that "cooperation, solidarity and dependency are the main values that guide family life in Algeria" (p.11). In his work, Boutafnoushat (1984) summarizes the characteristics of the Algerian family as follows,

The Algerian family is an extended family which contains several small families under what is called "the large house" (Al-Dar Al-Kabirah) in rural areas and "large tent" (AlKhiama(sic) Al-Kabirah) among the Bedouins ..... The Algerian family is patriarchal and extended (qtd in Achoui, 2006, p.247).

The notion of "the large house" or Al-Dar AL-Kabirah evoked in this quote indicates the collectivist aspect of the Algerian culture. Many gatherings on religious and social occasions like the Islamic feast of Eid, Ramadan, or the Yennayer day take place in Al-Dar Al-Kabirah. These gatherings most often include relatives within three generations. Even when one is married and 
has his own family, he is not supposed to celebrate these feasts with his small family, otherwise he is poorly judged by the other family members. Parents should accustom their children to these gatherings whose main objective is to maintain solidarity and loyalty among family members. Thus, the family structure and values in Algeria attest to a high degree of collectivism that stands across societal independence.

In high power distance cultures, formality in the educational realm is more than necessary. Because of formality and the unquestionable authority of the teacher, the latter takes control of both the teaching and learning processes, leaving no room for learners' autonomy and developing a paternalistic way of teaching. However, in the Algerian context, the teacher is not entirely blamed for the absence of learner autonomy; learners as well tend to uphold this paternalistic relationship.

This brings us to the question: where does autonomy begin? Autonomy starts before the child becomes a learner. Developing autonomy in life is a prerequisite for autonomy in learning. However, the Algerian socio-cultural environment does not encourage behavioral autonomy that is often constrained by considerations of "legitimate" paternalism. There is an argument against paternalism in school settings, which has been advanced most convincingly by the philosopher Lindley (1986), who argues that the various systems of regulation involved in schooling place severe constraints on learners' behavioral autonomy.

Criticizing the British schooling system of the 1980s, Lindley's critique is valid for the present Algerian schooling system. Lindley (1986) contends that paternalistic constraints may be legitimate as long as they do not impair children's autonomy in the long term. However, Lindley (1986) states, most schools fail this test for "an educational system which was geared to promote widespread autonomy amongst its pupils would provide an environment which stimulated critical self-awareness, a desire to question received wisdom, and self-directedness; and most schools are unable to provide this." (p.136)

The Algerian learner falls into this category for a variety of socio-cultural reasons. First, the family is the most essential unit of the Algerian social system, and defines social relationships. Because of the importance of the family unit, the individual is always subordinate to the group because it comes above all else and this is manifested through the widespread nepotism in Algeria. This subordination to the family group does not favor personal autonomy. There are various instances that showcase this impossibility to reach personal autonomy, the most famous of which are the issues of marriage and divorce that are not very personal in the Algerian context as these are family matters more than personal ones. Decision-making in these matters is not a person's business, but a family's one. If personal autonomy is not enhanced in the family circle, autonomy at large is unlikely to be achieved. These Algerian socio-cultural constraints for individual autonomy are the same to be responsible for the impossibility to develop learner autonomy in the educational realm. In sum, collectivist cultures and paternalistic methods hardly enhance learner autonomy; rather they further promote surface learning.

\section{Methods}

\section{Participants}

The researcher conducted her research among Algerian graduate students who were pursuing their Master degree at the University of Saida, Algeria during 2019/2020. The researcher 
selected the sample randomly. The researcher further divided respondents according to their gender and marital status. As table two indicates, respondents consisted of 25 males and 35 females. Twenty one respondents out of a total of 60 are married. They all live in Saida, a small conservative town in the west of Algeria. The researcher's distribution of the respondents according to their marital status is significant to the present research since the institution of marriage, and the Algerian family structure conceal collectivist deep-seated values.

Table 2. Distribution of participants according to gender and marital status

\begin{tabular}{|l|l|l|l|}
\hline \multicolumn{2}{|l|}{ Males } & Females \\
\hline 25 & Single & 35 & \multicolumn{2}{l|}{} \\
\hline Married & 18 & Married & Single \\
\hline 7 & 18 & 14 & 21 \\
\hline
\end{tabular}

\section{Research Instruments}

Since this research investigates a case study, the researcher used a qualitative approach using two research instruments, namely the Self-Directed Learning Readiness Scale (SDLRS) questionnaire (Guglielmino, 1977) and an interview with the informants who scored low in the SDLRS questionnaire. Initially, the researcher used the SDLRS, a 58-item five-point Likert-type questionnaire that measures the complexity of attitudes, skills, and characteristics that constitute an individual's level of readiness to manage his/ her learning (Guglielmino, 1977, www.guglielmino734.com). The questionnaire was highly significant in the identification of the respondents as either high self-directed learners or low self-directed learners. However, the questionnaire did not form any part of data analysis, and its main objective was to identify the respondents in terms of their readiness to use the self-directed approach. It is through the interview that the investigation of the socio-cultural cultural impress on self-directed learning was disclosed. However; the researcher could not interview all informants during the critical period of the Covid 19 lockdown. Between April and October 2020, only 15 informants accepted to be interviewed.

\section{Research Procedures}

The SDLRS questionnaire revealed that 20 respondents were high self-directed learners while 40 respondents were low self-directed learners. Since this research investigates the socio-cultural reason behind the slow emergence of self-directed learning, the researcher interviewed only those who scored low in the SDLRS questionnaire, namely four male students and 11 female students.

Table 3. Respondents' scores according to the SDLRS questionnaire

\begin{tabular}{|l|l|l|}
\hline Gender & High score & Low Score \\
\hline Female & 8 & 27 \\
\hline Male & 12 & 13 \\
\hline
\end{tabular}

The researcher created other categories among the 15 informants who accepted to be interviewed. As table four shows, six respondents are married out of a total of 15 . The married informants also indicated that they were either part-time or full-time workers. The researcher chooses to distribute the participants according to their marital status because the institution of marriage exhibits many of the Algerian cultural practices that decelerate autonomy. 
Arab World English Journal (AWEJ) Volume 12. Number 3. September 2021

The Socio-Cultural Impress on the Promotion of Self-Directed-Learning

BERREZOUG

Table 4. Distribution of respondents' according to their marital status

\begin{tabular}{|l|l|l|}
\hline & Male & Female \\
\hline Married & 1 & 5 \\
\hline Single & 3 & 6 \\
\hline
\end{tabular}

The researcher structured the interview questions in a way that would elicit the link between the respondents' cultural practices and traditions and their low scores in the SDLRS questionnaire.

\section{Discussion and Interpretation}

The four married female respondents agreed that to be self-directed learners, they need to sacrifice several valuable things, such as time for family, vacation, family gatherings. The respondents reported that this would cause uneasiness among family members, especially their families-in-law. They all agreed that the Algerian culture regarded a married woman's educational endeavor as accessorial, if not unnecessary. One respondent reported having been in serious trouble with her mother-in-law for missing the Yennayer gathering (Yennayer is the first month of the Amazigh year and corresponds to January in the Gregorian calendar. Algeria celebrates the beginning of the Amazigh year on January $12^{\text {th }}$ ). This stems from the impact of the collective social values that Algerians cherish. She further explained that breaking away from these socio-cultural traditions would result in harsh criticisms directed at its culprit. Another respondent reported her difficulty in making ends meet. Between housework, childcare, and her husband's frequent guests, she could only rely on her teachers' handouts.

The six female single participants' views did not diverge considerably from the married ones. They all agreed, although using different words, that Algeria's patriarchal system does not favor a woman's autonomy, in either life or education. One respondent reported being compelled by her father to enroll in a major that did not fit her aspirations. She explained that her father did not allow her to enroll at a distant university because he had a prejudiced conception of life at the campus. Another respondent reported that as a girl, she had less time to devote to her studies than her brother does. She explained that the reason behind such difference is the patriarchal system that subdues women to men. She reported that during Ramadan, for instance, she had to help her mother in the kitchen for almost the whole day. A girl's task at home, she added, is to help the mother, her homosocial, in the house chores. With a sentiment of injustice, she further argued that while she had little time left at home to devote to her studies, her brother could spend the whole day reading books without being interrupted.

The researcher found that the male respondent' low scores, however, concealed another aspect of the Algerian collectivist values. Three out of four male respondents unabashedly expressed their disinterest in their graduate studies. They explained that a man's bravery lies in his economic success and not in "how much he knows about Shakespeare," to use one of the respondent's phrases. The three respondents informed the researcher that they had little time to devote to their studies since they were part-time workers. For them, autonomy does not correspond to the Algerian man's collectivist mindset. The last male respondent's view was more explicit. He explained that to be a self-directed learner, one needs to have a minimum of autonomy in life. He found that this is not possible in Algeria when he opined "I am 22 and I still live with my parents and ask them for pocket money to buy my school furniture; how can I be autonomous in learning. Let's be realistic." 
Concerning the respondents' attitude towards their teachers, there was unanimity among the informants' that the teacher is a model, and their statements showed that they displayed dutiful deference to their teachers. They also regarded their teachers as more knowledgeable than them, and this reveals how the learner-teacher relationship is regulated by cultural value rather than pedagogical objectives.

Respondents also agreed that the class, the syllabus, and the course objectives should be designed by the teacher, who, they reiterate "is more knowledgeable in the field." Therefore, the paternalistic educational system legitimates the role of the teacher as the de facto master. The researcher concluded the interview with a general question on the Algerian culture's imprint on their learning process. All respondents agreed, at varying degrees, that culture has a significant impact on the way they learn.

\section{Research Implications}

Let us recall that self-directed learning is a western notion that was created in the democratic context, thus sparing its advocates the effort to foster independence into learners who are already brought up in an individualistic environment advocating autonomy. Does this mean that to achieve self-directed learning, we should westernize our societies? Or shall we abandon the idea since we cannot abandon our culture? In other words, is there any possibility to implement selfdirected learning in collectivist societies without questioning their socio-cultural practices or assimilating their subjects into the Western culture?

One possible positive answer to this question is glocalization, i.e. readjusting the global to the local culture to glocalize the practice of self-directed learning and come out with an Algerian version of the Knowlesian concept. If the solution to the pedagogical problem is glocalization, the question that remains is: how can we adapt this concept to our educational policies and regulations?

Before any suggestions are made, let us first delve into the notion of glocalization and what it implies in the educational field. Originally, glocalization was theoretically conceived as a result of Japanese business practices in the 1980s to blend and connect Japan (the local) with the rest of the world (the global) while maintaining its cultural significance. Patel and Lynch (2013) suggest, "Glocalized learning and teaching refers to the curricula consideration and pedagogical framing of local and global community connectedness in relation to social responsibility, justice and sustainability" (p.223). From a pedagogical standpoint, glocalization makes sense in the Algerian context primarily because of the multiple exchange programs adopted by the ministry of higher education, such as the ERASMUS program. In this particular context, the researcher still remembers Burundi, Malian, and Nigerian students who enrolled in our department a few years ago, and who were very active in class. These international students enriched my experience as a teacher and promoted their classmates' tolerance of diversity and difference. Many of our students benefit annually from university scholarships to different countries like Jordan, China, and England. For this particular reason, educational policies should be adapted to meet the global requirements since neither Algerian classroom nor foreign ones are nation bound. Learners in these classes become glocal, i.e. "they think globally and act locally" (Tien \& Talley, 2012, p.126). A culturally diverse classroom facilitates the implementation of selfdirected learning since international students come with different aspirations and perspectives. 
Thus, without compromising any of the cultural values of the Algerian society, the implementation of self-directed learning needs to be thought and worked out at university independently of the familial and cultural constraints that slow down its development. To engage in self-directed learning/teaching, it is very imperative to be aware of one thing, i.e. our students will be future workers in the global market that requires independence, individualism, and innovation. In the Algerian higher education system, there are two types of Master programs, namely academic Master programs, and professional master programs. The latter is meant to introduce Master graduates to the workforce as soon as they graduate. Thus, Learners at university should be continuously reminded that in the few years to come, they will not be measured by how much they know but by how well they can use what they learned to perform their work. Teachers should also call students' attention to the fact that they are accountable for what they know and how they learn as long as they are the only ones who can decide how learning experiences can be helpful to them in the future. If we succeed in reinforcing the link between learning and performance and get students to persistently ask the question: how can this learning sequence be functional in my future life? Only then can we instill self-directed learning. So, raising the learners' awareness of this fact will motivate them to engage in self-directed learning.

Moreover, reinforcing international exchange programs in a glocal framework will help learners create balance between the Algerian culture and the global one. One vital virtue of glocalization is its imminence in liberating pedagogical learning from cultural relativism that is becoming burdensome in higher education. Blending the local with the global, glocalization offers a more open and respectful dialogue between cultures. Patel and Lynch (2013) emphasize the significance of glocalization in higher education as it "rejects ethnocentrism that has long promoted the dominant worldview of judging other cultural communities through the parochial, tinted lens of one's own cultural standpoint" (p. 224). A fundamental step in moving the teaching/learning practices towards independence and collaboration is to relieve the learner from this binding ethnocentrism.

These exchange programs will also urge teachers to readjust their curricula to meet the needs and interests of students of different backgrounds. Welikala's (2011) notion of "the multiperspective curriculum" is of particular interest in this regard. Welikala (2011) rightfully opines that multi-perspective curricula represent the changes of the 21 st century universities where we "encounter the world in the classroom" (p. 24). He labels this encounter "the pedagogy of encounter" (p.25). Therefore, educators' preoccupation with the way learners encounter the world throughout the learning experiences that they offer them plays a vital role in advancing self-directed thinking. In sum, international exchange programs will benefit learners at many levels.

\section{Conclusion}

This paper was dedicated to a deeper investigation of the socio-cultural constraints to the implementation of self-directed learning in Algerian universities. This paper was dedicated to the study of whether Algerian socio-culture enhances or impedes self-directed learning. The main aim of the present study is to provide insights for program administrators, curriculum designers, and policy makers to work out a culturally suitable model of self-directed learning that would not compromise Algerian collectivist socio-cultural values. 
The examination of Algerian culture through the lens of Hofstede's six-D model leads to the conclusion that self-directedness is not compatible with Algerian culture. Two important characteristics of self-directed learning i.e., democracy and individualism are not components of the Algerian culture. What is more, the Algerian culture is in diametric opposition to selfdirected learning because of its collectivist and patriarchal values. However, this paper seeks to demonstrate that the ethnic cleansing argument that assumes that the adoption of western pedagogical values requires abandoning one's culture is not always plausible. Instead, this paper suggests that even if the Algerian culture is not compatible with self-directedness, this does not mean that the implementation of self-directed learning is impossible. Many options are available to start thinking seriously about working out new curricula that engage learners in their learning experiences. This paper briefly discusses possible suggestions that might help teachers in implementing self-directed learning in their classes, yet more research need to be done in this field to enlighten teachers and academics on the their practicability. For instance, higher education should open up possibilities for a more open and respectful dialogue between local learners and global ones. This can be done through the international exchange programs that not only culturally and ethnically diversify our classrooms but also urge teachers to adapt their curricula to needs and aspirations of learners of different ethnic and cultural backgrounds. Although these programs are at work in Algeria, they need to be reinforced. Moreover, teachers should adapt their curricula and teaching strategies to the 21 st century technological and geopolitical changes.

\section{About the author}

Dr Hanaà Berrezoug is Senior Lecturer of American studies at Dr Moulay Tahar University, Saida (Algeria). Her area of research includes American literature, American civilisation, race and ethnicity, and women's issues. She published several papers in the fields of literature and women's issues. She is author of The Hispanic Challenge to American National Identity (2019), and Course on American Drama (2021). ORCid: https://orcid.org/0000-0002-2355-0465

\section{References}

Ahmad, B. E., \& Abdul Majid, F. (2010). Self-directed Learning and Culture: a Study on Malay Adult Learners.Procedia Social and Behavioral Sciences, Elsevier, 7, 254-263. Doi:10.1016/j.sbspro.2010.10.036

Achoui, M. (2006). The Algerian Family: Change and Solidarity. In J. Georgas, J.W Berry, F.J.R.V de Vijver, C. Kagitcibasi \& Y.H Poortinga (eds.), Families across Cultures: A 30 Nation Psychological Study (pp. 243-250), London: Cambridge University Press.

Benchennane, D. (2017). Technological Impress on self-Directed Learning, El Ishৎã؟, 8, $27-44$.

Blaschke, L. M. (2012). Heutagogy and lifelong learning: A review of heutagogical practice and self-determined learning. International Review of Research in Open and Distance Learning, 13 (1), 56-71. Retrieved from http://www.irrodl.org/index.php/irrodl/article/view/1076/

Braman, O. R. (1998). The Cultural Dimension of Individualism and Collectivism as a Factor in Adult Self-Directed Learning Readiness, (Unpublished Doctoral Dissertation). University of Southern Mississippi, USA.

Brookfield, S. D. (1994). 'Self-directed learning', in YMCA George Williams College ICE301 Lifelong learning, Unit 1 Approaching lifelong learning. London: YMCA George Williams College. Retrieved from https://infed.org/mobi/self-directed-learning/ 
Ghout-Khenoune, L. (2019). Is There a Place for Learner Autonomy in Algerian EFL Learning Culture, Indpendence,77, 8-10.

Gibbons, M. (2003). The Self Directed Learning Handbook: Challenging Adolescent Students to Excel.John Wiley and Sons.

Guglielmino, L. M. (1977). Development of the Self-directed Learning Readiness Scale. Unpublished doctoral dissertation. The University of Georgia, USA.

Haddoune Sakraoui, A. (2019). Integrating Self - directed Learning into EFL: The Case of Third Year EFL Students Enrolled at the University of Badji Mokhtar Annaba (Algeria), ElTawassol, 25 (1), 164-175.

Hanrahan, M. (1998). The Effects of Learning Environment on Students' Motivation and Learning, International Journal of Science Education, 20 (6), 737-753. http://dx.doi.org/10.1080/0950069980200609

Hofstede, G. (2011). Dimentionalizing Cultures: The Hofstede Model in Context. Online Readings in Psychology and Culture, 2 (1), 1-26. https://doi.org/10.9707/2307-0919.1014

Keddie, N. (1980). Adult Education: An Ideology of Individualism. In J. L.Thompson,(ed.), Adult Education for a Change (pp. 45-64).London: Hutchinson.

Knowles, M.S. (1975). Self-Directed Learning, A Guide for Learners and Teachers. NewYork, Cambridge Books.

Lamb, T. (2009). Controlling Learning: Learners' Voices and Relationships between Motivation and Learner Autonomy. In S. Toogood, R. Pemberton \& A. Barfield (Eds.), Maintaining Control: Autonomy and Language Learning (pp. 67-86), Hong Kong University Press.

Lindley, R. (1986). Autonomy. London: Macmillan.

Naisbitt, N. (1984). Megatrends: Ten New Directions Transforming our Lives, London: Macdonald.

Patel, F.,\& Hayley, L. (2013). Glocalization as an Alternative to Internationalization in Higher Education: Embedding Positive Glocal Learning Perspectives.International Journal of Teaching and Learning in Higher Education, 25, (2), 223-230.

Sinclair, B. (2007). The Teacher as Learner: Developing Autonomy in an Interactive Learning Environment. In S. Toogood, R. Pemberton \& A. Barfield (Eds.), Maintaining Control: Autonomy and Language Learning (pp. 175-198), Hong Kong University Press.

Tien, C. Y., \&Talley, P. C. (2012). "Think globally, act locally": 'Glocalization' in Taiwanese higher education. International Journal of Business and Social Science, 3(15), 124-130.

Triandis, H.C. (1995). Individualism and collectivism. Boulder, CO: Westview Press.

Welikala, T. (2011). Rethinking international higher education curriculum: Mapping the research landscape. Nottingham, UK: Universitas 21 